\title{
Seizures and epilepsy secondary to viral infection in the central nervous system
}

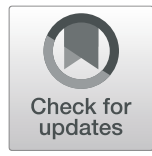

Peng Zhang, Yuting Yang, Jialin Zou, Xinrui Yang, Qiankun Liu and Yangmei Chen*

\begin{abstract}
Viral infection in the central nervous system (CNS) is a common cause of seizures and epilepsy. Acute symptomatic seizures can occur in the context of almost all types of acute CNS viral infection. However, late unprovoked seizures and epilepsy may not be frequent after viral infection of the CNS. The incidence of seizures and epilepsy after CNS viral infection is mainly dependent on the brain region of infection. It remains to be determined whether treatment of CNS viral infection using antiepileptic drugs (AEDs) can prevent seizures and subsequent epilepsy in patients, particularly with regard to the timing, drug choice and dosage, and duration of AEDs. The postoperative outcome of seizures in patients with intractable epilepsy caused by viral encephalitis primarily depends on the epileptogenic zone. In addition, neuroinflammation is known to be widely involved in the generation of seizures during CNS viral infection, and the effects of anti-inflammatory therapies in preventing seizures and epilepsy secondary to CNS viral infection require further studies. In this review, we discuss the incidence, mechanisms, clinical management and prognosis of seizures and epilepsy secondary to CNS viral infection, and summarize common CNS viral infections that cause seizures and epilepsy.
\end{abstract}

Keywords: Seizures, Epilepsy, Viral infection, Central nervous system

\section{Background}

Viral infections can cause a broad range of diseases in the central nervous system (CNS). Many types of CNS viral infections have characteristic geographic distribution patterns, and they can be transmitted across regions or countries through travel [1]. Understanding the epidemic regions of viruses is helpful for diagnosing viral infection in the CNS. In addition, with the development of molecular biological and neuroimaging techniques, the diagnosis of CNS viral infection is becoming more and more rapid and accurate.

Seizures are a common presenting symptom of CNS viral infection, and can occur during the acute phase of infection or late after recovery [2]. Acute symptomatic seizures can manifest in almost all types of acute CNS viral infection, while late unprovoked seizures and epilepsy may not be frequent after recovery from the acute

\footnotetext{
* Correspondence: chenym1997@camu.edu.cn

Department of Neurology, The Second Affiliated Hospital of Chongqing Medical University, Chongqing 400010, China
}

stage of infection [2]. Previous study has suggested that concurrent seizures with viral encephalitis are predictive of death and severe sequela on follow-up [3]. Theoretically, early management of seizures and epilepsy after CNS viral infection may improve prognosis. However, there are limited data on the timing, drug choice and dosage, and duration of antiepileptic drugs (AEDs) treatment. Neurosurgery is not always effective in producing an ideal seizure outcome, however, in certain subgroups of patients with postencephalitic epilepsy, the postoperative seizure outcome has been reported to be generally satisfactory [4].

In this paper, we provide a comprehensive overview on seizures and epilepsy secondary to viral infection in the CNS, primarily focusing on the clinical management and prognosis of seizures and epilepsy following CNS viral infection.

\section{Seizures and epilepsy in CNS viral infection}

Viral infection in the CNS can present with either acute symptomatic or late unprovoked seizures $[1,2]$. A large

(c) The Author(s). 2020 Open Access This article is licensed under a Creative Commons Attribution 4.0 International License, which permits use, sharing, adaptation, distribution and reproduction in any medium or format, as long as you give appropriate credit to the original author(s) and the source, provide a link to the Creative Commons licence, and indicate if changes were made. The images or other third party material in this article are included in the article's Creative Commons licence, unless indicated otherwise in a credit line to the material. If material is not included in the article's Creative Commons licence and your intended use is not permitted by statutory regulation or exceeds the permitted use, you will need to obtain permission directly from the copyright holder. To view a copy of this licence, visit http://creativecommons.org/licenses/by/4.0/ 
variety of CNS viral infections are associated with seizures $[1,2,4]$. The incidence of early seizures varies among CNS viral infections and is underestimated probably due to the underdiagnosis of nonconvulsive seizures [2]. Acute symptomatic seizures do not recur in general, but they may increase the risk of subsequent unprovoked seizures and epilepsy [1]. For example, a population-based study found that the 20-year-risk of late unprovoked seizures is $22 \%$ in viral encephalitis complicated by early seizures, and $10 \%$ in patients who have not experienced early seizures during viral encephalitis [5].

\section{Common CNS viral infections associated with seizures and epilepsy}

CNS viral infection is a prevalent etiology of seizures and acquired epilepsy. More than 100 types of viruses may cause encephalitis [1]. According to the epidemiological behavior, viral encephalitis can be classified into sporadic encephalitis and epidemic encephalitis [1, 2]. Most types of epidemic viral encephalitis are caused by arboviruses which are transmitted to humans by arthropods such as mosquitoes and ticks [2], and they have different characteristic geographical distributions [1]. Adequate knowledge on the epidemic regions of each type of virus is beneficial for clinical diagnosis of CNS viral infection. A list of common viruses associated with seizures and epilepsy is provided in Table 1.

Japanese encephalitis (JE), caused by Japanese encephalitis virus (JEV), is the most common acute epidemic encephalitis worldwide [1]. The associated factors for the occurrence of early seizures in patients with JE include young age, focal weakness, electroencephalogram (EEG) slowing, a low score on the Glasgow Coma Scale, increased intracranial pressure, as well as cortical and thalamic involvement on computed tomography or magnetic resonance imaging [2, 20]. Previous studies have shown that $50-80 \%$ of JE cases have seizures [21]; more specifically, $61 \%$ of children versus $37 \%$ of adult patients manifest with seizures [2]. Notably, repeated status epilepticus (SE) is associated with poor prognosis [20]. Clinical investigative findings have suggested that JE should be highly suspected in patients who develop symptoms of CNS viral infection in the epidemic regions of JE, for which virological and serological tests should be performed to verify the suspicion.

Dengue is largely endemic in tropical and sub-tropical countries. Dengue encephalitis is an infrequent but critical complication of Dengue virus infection. Seizures are common in dengue encephalitis cases with an incidence of $47 \%$ and are typically generalized [22-24].

Herpes simplex encephalitis (HSE) is the most common type of sporadic encephalitis and most of the cases are caused by Herpes simplex virus type 1 (HSV-1) $[19,25]$. The most common clinical symptoms of HSE include fever, seizures, headache, and focal neurological deficits [26]. HSE inflammation is characterized by hemorrhagicnecrotizing inflammation, a predisposition to occur in epileptogenic areas within the fronto-temporal regions, and the involvement of cerebral cortex [19, 27, 28], which can partly explain the high incidence of seizures during HSE. Previous studies indicated that $75 \%$ of HSE cases have seizures in the acute stage of infection [29], 40-65\% of adult patients present with late unprovoked seizures after resolution of HSE symptoms [30, 31], and 29\% of HSE patients have SE [32], which is more intractable than other causes $[33,34]$. The main seizure types associated with HSE are focal seizures followed by generalized seizures [35]. Notably, HSV can remain in the CNS tissue for a long time after primary infection [36], forming a source of HSV reactivation, which can be induced under conditions of stress, ultraviolet light, immunosuppressed state, intercurrent infection, hormonal changes, epilepsy surgery and trigeminal ganglia operation [37-40], thus resulting in HSE recurrence.

Other types of herpes viruses only contribute to a small proportion of encephalitis cases. Cytomegalovirus (CMV) is a frequent cause of intrauterine infection [41-43] and is closely related to postnatal seizures $[44,45]$. However, approximately $90 \%$ of cases with congenital CMV infection are asymptomatic [46], while only $10-15 \%$ of infant cases have clinical symptoms or signs at birth [47]. The incidence of postnatal seizures in symptomatic infected children ranges from 10 to $56 \%$, whereas the rate is $0.9 \%$ in asymptomatic patients [48-50].

Human immunodeficiency virus (HIV) infection has become a common etiology for new-onset seizures especially in developing countries [1]. Seizures have been reported in $2-20 \%$ of cases with HIV infection [51], and most of them manifest generalized seizures; in contrast, partial seizures are rarely observed [52-55]. Causes for the seizures in patients with acquired immune deficiency syndrome include cerebral HIV infection, and more commonly, secondary opportunistic CNS infection [1]. Progressive multifocal leukoencephalopathy (PML) is a rare opportunistic viral infection caused by a common John Cunningham virus (JCV) in immunocompromised individuals, especially those with advanced HIV infection. In a previous study of Miskin et al., 44\% of PML survivors had seizures, and $25 \%$ had seizures immediately at the onset of PML symptoms [56]. Hyperintense cortical signal on T1-weighted precontrast magnetic resonance images and immune reconstitution inflammatory syndrome are both related to seizures in patients with PML $[57,58]$.

Mumps virus and Measles virus are members of the Paramyxoviridae family and are implicated in encephalitis. Subacute sclerosing panencephalitis (SSPE) is a progressive fatal disease caused by Measles virus [59]. In an 
Table 1 Common viruses associated with seizures and epilepsy

\begin{tabular}{|c|c|c|c|c|c|}
\hline $\begin{array}{l}\text { Genus or family } \\
\text { [6] }\end{array}$ & $\begin{array}{l}\text { Virus and type of } \\
\text { nucleic acid [6] }\end{array}$ & Route of transmission & $\begin{array}{l}\text { Geographical } \\
\text { distribution }\end{array}$ & $\begin{array}{l}\text { Peak seasonal } \\
\text { incidence }\end{array}$ & Laboratory testing \\
\hline \multirow[t]{3}{*}{ Flaviviridae } & $\begin{array}{l}\text { Japanese } \\
\text { encephalitis virus } \\
\text { (RNA virus) }\end{array}$ & Transmitted by genus Culex & $\begin{array}{l}\text { India, China, Japan, } \\
\text { South East Asia, Eastern } \\
\text { Mediterranean region, } \\
\text { Papua New Guinea, } \\
\text { Australia [1] }\end{array}$ & Summer and early fall & $\begin{array}{l}\text { CSF PCR; serum and CSF } \\
\text { IgM (elevated in CSF in the } \\
\text { first few days, sensitivity } \\
\text { and specificity }>90 \% \text { ) and } \\
\text { IgG [7] }\end{array}$ \\
\hline & $\begin{array}{l}\text { Dengue virus (RNA } \\
\text { virus) }\end{array}$ & Transmitted by genus Aedes & $\begin{array}{l}\text { India, China, Japan, } \\
\text { South East Asia, Eastern } \\
\text { Mediterranean region, } \\
\text { Papua New Guinea, } \\
\text { Australia [8] }\end{array}$ & Summer and early fall & $\begin{array}{l}\text { PCR or antigen testing of } \\
\text { respiratory secretions [8] }\end{array}$ \\
\hline & $\begin{array}{l}\text { Zika virus (RNA } \\
\text { virus) }\end{array}$ & $\begin{array}{l}\text { Transmitted by genus Aedes; } \\
\text { mother-to-child transmission } \\
\text { through placenta; sexual } \\
\text { transmission [9] }\end{array}$ & $\begin{array}{l}\text { Africa, South America, } \\
\text { Southeast Asia (Pacific } \\
\text { region) }\end{array}$ & $\begin{array}{l}\text { More frequent in } \\
\text { summer and early fall } \\
\text { (in the temperate } \\
\text { zone); no seasonality } \\
\text { (in the tropics) }\end{array}$ & $\begin{array}{l}\text { Serum or urine PCR; serum } \\
\text { or CSF IgM [9] }\end{array}$ \\
\hline \multirow[t]{4}{*}{ Herpesviridae } & $\begin{array}{l}\text { Herpes simplex } \\
\text { virus (DNA virus) }\end{array}$ & Sexual; contact transmission & Worldwide & No seasonality & $\begin{array}{l}\text { CSF PCR [8]; CSF IgG (if } \\
\text { neurological manifestations } \\
\text { last more than a week) [10, } \\
\text { 11] }\end{array}$ \\
\hline & $\begin{array}{l}\text { Cytomegalovirus } \\
\text { (DNA virus) }\end{array}$ & $\begin{array}{l}\text { Mother-to-child transmission } \\
\text { through placenta, labour, } \\
\text { breast milk; sexual } \\
\text { transmission; blood } \\
\text { transfusion }\end{array}$ & Worldwide & No seasonality & $\begin{array}{l}\text { Serum and CSF PCR; serum } \\
\text { and CSF IgM or IgG [8] }\end{array}$ \\
\hline & $\begin{array}{l}\text { Varicella zoster } \\
\text { virus (DNA virus) }\end{array}$ & $\begin{array}{l}\text { Close contact and droplet } \\
\text { transmission [12] }\end{array}$ & Worldwide & $\begin{array}{l}\text { All seasons, more } \\
\text { frequently in late } \\
\text { winter and spring [12] }\end{array}$ & CSF PCR \\
\hline & $\begin{array}{l}\text { Epstein Barr virus } \\
\text { (DNA virus) }\end{array}$ & $\begin{array}{l}\text { Saliva or droplets } \\
\text { transmission [13] }\end{array}$ & Worldwide & No seasonality & $\begin{array}{l}\text { CSF PCR; serum viral capsid } \\
\text { antigen, IgM [14] }\end{array}$ \\
\hline Retroviridae & $\begin{array}{l}\text { Human } \\
\text { immunodeficiency } \\
\text { virus (RNA virus) }\end{array}$ & $\begin{array}{l}\text { Sexual transmission; direct } \\
\text { contact; blood or blood } \\
\text { products }\end{array}$ & $\begin{array}{l}\text { Sub-Saharan Africa, } \\
\text { Central Asia, Latin, } \\
\text { America, Eastern Europe } \\
\text { [1] }\end{array}$ & No seasonality & PCR or serum IgG \\
\hline \multirow[t]{3}{*}{ Paramyxoviridae } & $\begin{array}{l}\text { Measles virus (RNA } \\
\text { virus) }\end{array}$ & $\begin{array}{l}\text { Droplet transmission; direct } \\
\text { contact with nasal or throat } \\
\text { secretions [15] }\end{array}$ & Worldwide [8] & $\begin{array}{l}\text { All seasons, more } \\
\text { frequently in late } \\
\text { spring }\end{array}$ & $\begin{array}{l}\text { Serum IgM; CSF PCR; } \\
\text { nasopharyngeal, throat or } \\
\text { urine PCR [8] }\end{array}$ \\
\hline & $\begin{array}{l}\text { Mumps virus (RNA } \\
\text { virus) }\end{array}$ & Droplet transmission & Worldwide [8] & $\begin{array}{l}\text { Winter and spring (in } \\
\text { the temperate zone); } \\
\text { no seasonality (in the } \\
\text { tropics) [16] }\end{array}$ & $\begin{array}{l}\text { Serum IgM; CSF PCR (high } \\
\text { sensitivity); viral isolation } \\
\text { from CSF, saliva, urine [8] }\end{array}$ \\
\hline & $\begin{array}{l}\text { Nipah virus (RNA } \\
\text { virus) }\end{array}$ & $\begin{array}{l}\text { Droplet transmission; direct } \\
\text { contact transmission (bats- } \\
\text { to-human, pigs-to-human, } \\
\text { human-to-human occasion- } \\
\text { ally) [17] }\end{array}$ & $\begin{array}{l}\text { Bangladesh, India, } \\
\text { South-East Asia, } \\
\text { Australia [8] }\end{array}$ & $\begin{array}{l}\text { More frequent from } \\
\text { January to May [18] }\end{array}$ & $\begin{array}{l}\text { Serum and CSF IgM/lgG; } \\
\text { CSF, serum and urine PCR } \\
{[8]}\end{array}$ \\
\hline Orthomyxoviridae & $\begin{array}{l}\text { Influenza (RNA } \\
\text { virus) }\end{array}$ & $\begin{array}{l}\text { Droplet transmission; } \\
\text { contact transmission }\end{array}$ & $\begin{array}{l}\text { Worldwide distribution } \\
\text { but encephalopathy } \\
\text { most frequently } \\
\text { reported in Japan and } \\
\text { Australia [8] }\end{array}$ & Winter and spring & $\begin{array}{l}\text { Nasopharyngeal swab, } \\
\text { respiratory secretions PCR } \\
\text { [19] }\end{array}$ \\
\hline
\end{tabular}

CSF: cerebrospinal fluid; PCR: polymerase chain reaction; IgM: immunoglobulin M; IgG: immunoglobulin G

earlier study, $43 \%$ of patients with SSPE develop epilepsy, and the epileptogenic activities are mainly localized in the frontal lobe (58\%) [59].

Emerging viral infectious diseases include old infections that have recently spread to new geographic locations, infected new host species, or changed their pathology and morbidity, and new infections by previously unknown pathogens $[1,60]$. Examples of emerging viral infections include Nipah virus infection that spread from Malaysia to Bangladesh and India [1, 2, 61], and Zika virus (ZIKV), which is the latest member of arboviruses and causes sporadic illness at first and then large outbreaks in the Pacific [62]. 
A previous study showed that in cases of acute Nipah encephalitis, $23-27 \%$ of them had seizures and $30-54 \%$ of them had continuous segmental myoclonus [61]. Comparatively, seizures commonly occur in patients with relapsing Nipah encephalitis [1, 61]. ZIKV infection during pregnancy can cause congenital Zika syndrome (CZS), a distinct pattern of birth defects and disabilities, as ZIKV tends to attack the embryo matrix of fetal brain [63]. ZIKV infection can cause a broad range of underlying neurological abnormalities and frequent epileptic seizures [9]. Epilepsy has been observed in infants with CZS during their first year of life [64]. The incidence of epilepsy according to previous studies ranges from 9 to $71.4 \%$ [64-69], with the main seizure types being epileptic spasms $(72 \%)$ followed by focal motor seizures (21\%), and tonic seizures (4\%) [69].

\section{Mechanisms of seizures and epilepsy in CNS viral infection}

The incidence of seizures and epilepsy varies among different types of CNS viral infections, which is thought to be largely dependent on the anatomic location of the lesion [2]. HSV predominantly involves the mesial temporal lobe which is known to be a highly epileptogenic brain region, while other viruses such as JEV and West Nile virus generally affect subcortical structures and spare cerebral cortex $[1,2]$.

Neurotropic viruses can invade the CNS via blood or axonal transport, and induce neuronal injury, abnormal modification of neural circuits linked to seizure cascade, and production of proinflammatory cytokines during infection $[1,6,70]$. The proinflammatory cytokines can activate the innate immune system as well as the adaptive immune system [70]. The activated macrophages and microglia, effector cells of the innate immunity, can produce interleukin (IL)-6 and tumor necrosis factor (TNF)- $\alpha$ during viral infection [71-73]. A previous study has found that the number of infiltrating macrophages, which are inflammatory cells, reaches a peak coincidently with the peak of post-infectious seizures during CNS viral infection [74]. The inflammatory macrophages play a role in the clearance of virus from the brain, but at the same time may trigger seizures via promoting the production of IL-6 [71]. The proinflammatory cytokines such as IL- 6 and TNF- $\alpha$ have been demonstrated to disrupt the neuronal excitation/inhibition balance and increase neuronal hyperexcitability $[71,75,76]$. In a murine model of Theiler's encephalomyelitis virusinduced seizures, researchers found significantly decreased inhibitory currents and markedly increased excitatory currents in CA3 pyramidal neurons during the acute phase of viral infection [77, 78]. In addition, previous studies have revealed that inflammatory cytokines may break down the blood-brain barrier, leading to cerebral edema and ultimately triggering seizures $[1,79,80]$. The acute symptomatic seizures secondary to CNS viral infection may induce functional and structural alterations of the brain such as neuronal loss, neurogenesis, activation of microglia and astrocytes, gliosis, and neural circuit alteration, which in turn promote epileptogenesis and subsequent epilepsy [70, 81].

\section{Clinical management and prognosis}

Rapid diagnosis and timely initiation of antiviral treatment are essential for an optimal outcome in patients with CNS viral infection [19]. Evidence for the effectiveness of routine use of corticosteroids in treating CNS viral infection is insufficient [19]. Empirical interventions should be implemented in patients suspected clinically to have CNS viral infection despite the fact that virological tests remains uncompleted [82, 83].

The occurrence of seizures during the course of CNS viral infection is closely related to severe sequelae and indicates a high risk of subsequent epilepsy [26, 84]. Theoretically, prophylactic use of AEDs for primary or secondary prevention may potentially improve prognosis. In a previous systematic review, Pandey et al. intended to determine the primary and secondary preventive effects of prophylactic AEDs use on the occurrence of seizures in patients with viral encephalitis, but failed to obtain any relatively high-quality publications [85]. In addition, the timing, specific agent and dosage, and duration of AEDs have not been well-established due to the lack of evidence-based information [85]. Further studies on these topics are required. In clinical practice, AEDs are commonly used for preventing additional seizure after the first acute symptomatic seizure has occurred during the acute stage of infection [86]. The duration of prophylactic use of AEDs can range from 1 to 6 months in patients with complicated acute brain insults $[86,87]$, and the choice of AEDs mainly depends on the seizure type [88]. Narrow-spectrum AEDs (e.g., carbamazepine, oxcarbazepine, phenytoin, and lacosamide) are considered for decreasing seizure frequency in patients with focal seizures [88-90]. Broadspectrum AEDs (e.g., lamotrigine, levetiracetam, topiramate, valproate, and zonisamide) are typically used in patients with focal seizures or most generalized seizures [88-90]. Long-term antiepileptic medication is recommended when the diagnosis of epilepsy following CNS viral infection is established. If the first AED titrated to a therapeutic dose fails to control seizures, adding a second AED may increase the probability of achieving the goal of seizure-free [91]. The duration of antiepileptic therapy in post-infectious epilepsy should be customarized. It is reasonable to consider AEDs withdrawal in those who has been seizure-free for at least 2 years [88, 92-94]. In addition, it is commonly accepted that 
antiepileptic therapy be initiated once the diagnosis of SE is established. Rapid initiation of AEDs treatment, start of critical care and simultaneous monitoring are strongly recommended until clinical and electrographic seizures are halted [95].

Adrenocorticotropic hormone is considered an effective treatment for infantile spasms, but it may cause severe side effects in patients presenting infantile spasm after CMV infection due to its suppression of immune response [96-98]. Notably, previous study has reported that $56 \%$ of patients with infantile spasm and CMV infection achieve cessation of seizures after ganciclovir and AEDs treatment [99]. This indicates that a combined antiviral and antiepileptic regimen is preferred in order to avoid potential side effects induced by steroid therapy.

Several antiviral agents are principally metabolized by CYP3A4, but most old-generation AEDs can induce or inhibit such enzymatic function, which lead to the alterations of plasma concentrations of antiviral drugs [100]. Therefore, the efficacy of antiviral drugs should be reassessed when antiviral and antiepileptic agents are administered together. Valproic acid, a strong inhibitor of hepatic enzymes, can inhibit the metabolism of zidovudine [101]. On the contrary, carbamazepine, an enzymeinduced antiepileptic drug, significantly reduces the plasma concentration of indinavir, and the dose of which may need to be increased [102]. Notably, second- or third-generation AEDs such as levetiracetam, lamotrigine, gabapentin and brivaracetam may be favorable options as they have less effect on enzymatic function of CYP3A4 [103].

Epilepsy secondary to CNS viral infection is usually intractable, even with the use of multiple ADEs [26, 104, 105]. Patients with intractable epilepsy due to CNS viral infection should be considered as candidates for epilepsy surgery [106]. However, previous studies have found that the seizure outcomes after neurosurgery are not ideal as the lesions of CNS viral infection are generally widely distributed $[4,107,108]$. Notably, there is evidence that certain patients may have a favorable prognosis after epilepsy surgery. A recent study has indicated that in patients with postencephalitic epilepsy who were completely seizure-free or had significant improvement after operation, the seizure onset area was located either in the anteromesial temporal structures or focal gyrus; while in patients who had a relatively poor postoperative seizure outcome, the seizure started from multiple lobes [107]. Therefore, rigorous presurgical evaluation should be performed to determine which patients with intractable epilepsy secondary to CNS viral infection are suitable for surgical treatment. Stereoelectroencephalography or electrocorticography should be performed to elucidate the epileptogenic zone since scalp EEG is generally inadequate for presurgical evaluation [106, 107].
Remarkably, after initial infection, HSV can establish persistent latent infections in the CNS, acting as a source of HSE recurrence $[109,110]$. HSV reactivation after HSE rarely occurs to our knowledge, but there have been reports of HSE recurrence after neurosurgery for postencephalitic epilepsy [110, 111]. Therefore, antiviral agents should be considered for prophylactic preoperative treatment in postencephalitic epilepsy patients with known histories of HSE $[109,110]$.

Immune inflammatory response after CNS viral infection is a common pathophysiological mechanism that leads to seizures and epilepsy [1]. Animal experiments showed that anti-inflammatory therapy may be beneficial in improving the seizure threshold [112]. Further clinical trials are required to assess the effects of anti-inflammatory drugs in seizures and epilepsy secondary to CNS viral infection.

Notably, recent studies have indicated a possible association of CNS viral infection with subsequent autoimmune encephalitis (AE) [113-117]. AE is also one of the causes of seizures and epilepsy [118]. Neuronal injury and neuroinflammation induced by CNS viral infection can lead to the exposure of neuronal surface proteins, which triggers subsequent generation of antibodies against these antigens $[113,119]$. In addition, molecular mimicry has been involved in the pathogenesis of $\mathrm{AE}$ after viral infection of the CNS $[113,114]$. In a recent prospective study in a cohort of patients with HSE, 27\% of the cases developed $\mathrm{AE}$ associated with autoimmune responses against $\mathrm{N}$-methyl- $D$-aspartate receptor and other neuronal surface proteins within 3 months after antiviral therapy [113]. In addition, there were no differences in the use of AEDs or immunotherapy during HSE between $\mathrm{AE}$ and non-AE groups [113]. However, as the number of cases in this study is relatively small, whether prophylactic use of AEDs or immunotherapy during CNS viral infection is effective in preventing the development of $\mathrm{AE}$ requires further investigations.

\section{Conclusion}

Both acute symptomatic and late unprovoked seizures are associated with CNS viral infection. The incidence of seizures and epilepsy differs among various CNS viral infections, which may be attributed to the different brain regions involved by different types of viruses. Routine prophylactic use of ADEs in patients with CNS viral infection remains controversial, and the postoperative seizure outcome primarily depends on the epileptogenic zone. The immune inflammatory response during CNS viral infection is a frequent pathophysiological mechanism that leads to seizures and epilepsy, and antiinflammatory therapy may be advantageous for a better seizure outcome. Currently, there are limited data on the incidence, clinical management and prognosis of seizures and epilepsy secondary to CNS viral infection, so further investigations are needed to advance understanding in these facets. 


\section{Abbreviations}

AE: Autoimmune encephalitis; AED: Antiepileptic drug;

CMV: Cytomegalovirus; CNS: Central nervous system; CSF: Cerebrospinal fluid; CZS: Congenital Zika syndrome; EBV: Epstein Barr virus;

EEG: Electroencephalogram; HIV: Human immunodeficiency virus; HSE: Herpes simplex encephalitis; HSV: Herpes simplex virus; HSV-1: Herpes simplex virus type 1; IL: Interleukin; JCV: John Cunningham virus; JE: Japanese encephalitis; JEV: Japanese encephalitis virus; PML: Progressive multifocal leukoencephalopathy; SE: Status epilepticus; SSPE: Subacute sclerosing panencephalitis; TNF: Tumor necrosis factor; VZV: Varicella zoster virus; ZIKV: Zika virus

\section{Acknowledgements}

None.

\section{Authors' contributions}

PZ made substantial contributions to the content of the study, drafted and revised the manuscript, and read and approved the final manuscript. YY, JZ, $X Y$ and QL drafted and revised the manuscript, and read and approved the final manuscript. YC made substantial contributions to the content of the study, revised the manuscript, and read and approved the final manuscript.

\section{Funding}

This work was supported by the National Natural Science Foundation of China (No. 81571259 and No. 81771390).

\section{Availability of data and materials}

Not applicable.

\section{Ethics approval and consent to participate}

Not applicable.

\section{Consent for publication}

Not applicable.

\section{Competing interests}

The authors declare that they have no competing interest.

Received: 10 April 2020 Accepted: 3 July 2020

Published online: 08 August 2020

\section{References}

1. Singhi P. Infectious causes of seizures and epilepsy in the developing world. Dev Med Child Neurol. 2011;53(7):600-9.

2. Misra UK, Tan CT, Kalita J. Viral encephalitis and epilepsy. Epilepsia. 2008; 49(Suppl 6):13-8.

3. Zhao L, Zhou M, Wang B, Guo J, Chen N, He L. Clinical characteristics and outcome of clinically diagnosed viral encephalitis in Southwest China. Neurol Sci. 2015;36(12):2191-7.

4. Liu Y, Zhou W. Clinical features and surgical treatment of epilepsy after viral encephalitis. Brain Science Advances. 2019;5(1):41-50.

5. Annegers JF, Hauser WA, Beghi E, Nicolosi A, Kurland LT. The risk of unprovoked seizures after encephalitis and meningitis. Neurology. 1988; 38(9):1407-10.

6. Getts DR, Balcar VJ, Matsumoto I, Müller M, King NJ. Viruses and the immune system: their roles in seizure cascade development. J Neurochem. 2008;104(5):1167-76

7. Burke DS, Nisalak A, Ussery MA, Laorakpongse T, Chantavibul S. Kinetics of $\operatorname{lgM}$ and IgG responses to Japanese encephalitis virus in human serum and cerebrospinal fluid. J Infect Dis. 1985;151(6):1093-9.

8. Venkatesan A, Murphy OC. Viral encephalitis. Neurol Clin. 2018;36(4):705-24.

9. Carod-Artal FJ. Neurological complications of Zika virus infection. Expert Rev Anti-Infect Ther. 2018;16(5):399-410

10. Lakeman FD, Whitley RJ. Diagnosis of herpes simplex encephalitis: application of polymerase chain reaction to cerebrospinal fluid from brainbiopsied patients and correlation with disease. National Institute of Allergy and Infectious Diseases collaborative antiviral study group. J Infect Dis. 1995: 171(4):857-63.

11. Steiner I, Schmutzhard E, Sellner J, Chaudhuri A, Kennedy PG. European Federation of Neurological Sciences, et al. EFNS-ENS guidelines for the use of PCR technology for the diagnosis of infections of the nervous system. Eur J Neurol. 2012:19(10):1278-91.

12. Arvin AM. Varicella-zoster virus. Clin Microbiol Rev. 1996;9(3):361-81.

13. Kerr JR. Epstein-Barr virus (EBV) reactivation and therapeutic inhibitors. J Clin Pathol. 2019;72(10):651-8.

14. Rodrigo-Armenteros P, Kapetanovic-García S, Antón-Méndez L, GómezMuga JJ, Río EB, Fernández-Cuesta MÁ, et al. Akinetic mutism and status epilepticus due to Epstein Barr virus encephalitis. Clin Neurol Neurosurg. 2019;185:105492.

15. Weldegiorgis BH, Daniel MO. Computational modelling and optimal control of measles epidemic in human population. Biosystems. 2020;190:104102.

16. Beleni Al, Borgmann S. Mumps in the vaccination age: global epidemiology and the situation in Germany. Int J Environ Res Public Health. 2018;15(8): 1618.

17. Clayton BA. Nipah virus: transmission of a zoonotic paramyxovirus. Curr Opin Virol. 2017;22:97-104

18. World Health Organization. Nipah Baseline Situation Analysis. 2018. http:// www.who.int/blueprint/priority-diseases/key-action/WHO_NIPAH_baseline_ situation_analysis 27Jan2018.pdf?ua=1\&ua=1.

19. Kramer AH. Viral encephalitis in the ICU. Crit Care Clin. 2013;29(3):621-49.

20. Misra UK, Kalita J. Seizures in Japanese encephalitis. J Neurol Sci. 2001; 190(1-2):57-60

21. Ooi MH, Lewthwaite P, Lai BF, Mohan A, Clear D, Lim L, et al. The epidemiology, clinical features, and long-term prognosis of Japanese encephalitis in Central Sarawak, Malaysia, 1997-2005. Clin Infect Dis. 2008; 47(4):458-68.

22. Varatharaj A. Encephalitis in the clinical spectrum of dengue infection Neurol India. 2010;58(4):585-91.

23. Verma R, Varatharaj A. Epilepsia partialis continua as a manifestation of denque encephalitis. Epilepsy Behav. 2011;20(2):395-7.

24. Assenza F, Tombini M, Assenza G, Campana C, Benvenga A, Brunelli N, et al. Dengue encephalitis presenting with nonconvulsive status epilepticus: A case report. Clin Neurol Neurosurg. 2016;150:89-91.

25. Flore $R$, Claire D, Henri A. Herpes simplex encephalitis : from virus to therapy. Infect Disord Drug Targets. 2011;11(3):325-50.

26. Sellner J, Trinka E. Seizures and epilepsy in herpes simplex virus encephalitis: current concepts and future directions of pathogenesis and management. J Neurol. 2012:259(10):2019-30

27. Cheema Z, Khelaeni B, Bakshi R, Hassan A, Wasay M, Mekan SF, et al. Extra temporal involvement in herpes simplex encephalitis. Eur J Neurol. 2005; 12(6):475-9.

28. Mekan SF, Wasay M, Khelaeni B, Saeed Z, Hassan A, Sheerani M. Herpes simplex encephalitis: analysis of 68 cases from a tertiary care hospital in Karachi. Pakistan J Pak Med Assoc. 2005:55(4):146-8.

29. Misra UK, Kalita J. Seizures in encephalitis: predictors and outcome. Seizure. 2009;18(8):583-7.

30. Fang PC, Chen YJ, Chow JC. Clinical characteristics and prognostic factors of postencephalitic epilepsy in children. J Child Neurol. 2006;21(12):1047-51.

31. Elbers JM, Bitnun A, Richardson SE, Ford-Jones EL, Tellier R, Wald RM, et al. A 12-year prospective study of childhood herpes simplex encephalitis: is there a broader spectrum of disease. Pediatrics. 2007;119(2):e399-407.

32. Misra UK, Kalita J, Nair PP. Status Epilepticus in central nervous system infections: an experience from a developing country. Am J Med. 2008 121(7):618-23.

33. Mayer Stephan A, Jan C, Johnny L, Felicia M, Dennis Lyle J, Brian-Fred F. Refractory status epilepticus: frequency, risk factors, and impact on outcome. Arch Neurol, 2002:59(2):205-10.

34. Holtkamp M, Othman J, Buchheim K, Meierkord H. Predictors and prognosis of refractory status epilepticus treated in a neurological intensive care unit. Neurol Psychiatry. 2005;76(4):534-9.

35. Whitley RJ, Alford CA, Hirsch MS, Schooley RT, Luby JP, Aoki FY, et al. Vidarabine versus acyclovir therapy in herpes simplex encephalitis. N Engl J Med. 1986;314(3):144-9.

36. Eeg-Olofsson O. Virological and immunological aspects of seizure disorders. Brain Dev. 2003;25(1):9-13.

37. Mandyla H, Anagnostakis D, Koutsovitis P, Siahanidou T, Youroukos S. Late recurrence of herpes simplex virus meningoencephalitis in two infants. Eur J Pediatr. 2001;160(12):732-5.

38. De Tiège X, Rozenberg F, Burlot K, Gaudelus J, Ponsot G, Héron B. Herpes simplex encephalitis: diagnostic problems and late relapse. Dev Med Child Neurol. 2006;48(1):60-3. 
39. Knickelbein JE, Khanna KM, Yee MB, Baty CJ, Kinchington PR, Hendricks RL. Noncytotoxic lytic granule-mediated CD8+ T cell inhibition of HSV-1 reactivation from neuronal latency. Science. 2008;322(5899):268-71.

40. Yodko H, Spiegel R, Lumelsky D, Habib A, Miron D, Horovitz Y. Late relapse of herpes simplex virus encephalitis in a child due to reactivation of latent virus: clinicopathological report and review. J Child Neurol. 2008;23(3):344-8.

41. Caroppo S, Primache V, Barbi M, Binda S. Neonatal screening for congenital cytomegalovirus infection and hearing loss. J Clin Virol. 2006;35(2):206-9.

42. Pargman S, Berga S, Raynor BD, Jamieson DJ, Theiler RN, McPheeters M, et al. Umbilical cord blood screening for cytomegalovirus DNA by quantitative PCR. J Clin Virol. 2006;37(4):313-6.

43. Endo T, Goto K, Ito K, Sugiura T, Terabe K, Cho S, et al. Detection of congenital cytomegalovirus infection using umbilical cord blood samples in a screening survey. J Med Virol. 2009;81(10):1773-6.

44. Dollard SC, Ross DS, Grosse SD. New estimates of the prevalence of neurological and sensory sequelae and mortality associated with congenital cytomegalovirus infection. Rev Med Virol. 2007;17(5):355-63.

45. Cannon MJ. Congenital cytomegalovirus (CMV) epidemiology and awareness. J Clin Virol. 2009;46(Suppl 4):S6-6S10.

46. Kenneson A, Cannon MJ. Review and meta-analysis of the epidemiology of congenital cytomegalovirus (CMV) infection. Rev Med Virol. 2007;17(4):253-76.

47. Demmler GJ. Infectious Diseases Society of America and centers for disease control. Summary of a workshop on surveillance for congenital cytomegalovirus disease. Rev Infect Dis. 1991;13(2):315-29.

48. Pass RF, Stagno S, Myers GJ, Alford CA. Outcome of symptomatic congenital cytomegalovirus infection: results of long-term longitudinal follow-up. Pediatrics. 1980:66(5):758-62.

49. Bale JF Jr, Blackman JA, Sato Y. Outcome in children with symptomatic congenital cytomegalovirus infection. J Child Neurol. 1990;5(2):131-6.

50. Boppana SB, Fowler KB, Vaid Y, Hedlund G, Stagno S, Britt WJ, et al. Neuroradiographic findings in the newborn period and long-term outcome in children with symptomatic congenital cytomegalovirus infection. Pediatrics. 1997:99(3):409-14.

51. Sinha S, Satishchandra P. Seizures in HIV-seropositive individuals: NIMHANS experience and review. Epilepsia. 2008;49(Suppl 6):33-41.

52. Holtzman DM, Kaku DA, So YT. New-onset seizures associated with human immunodeficiency virus infection: causation and clinical features in 100 cases. Am J Med. 1989;87(2):173-7.

53. Wong MC, Suite ND, Labar DR. Seizures in human immunodeficiency virus infection. Arch Neurol. 1990:47(6):640-2.

54. Van Paesschen W, Bodian C, Maker H. Metabolic abnormalities and newonset seizures in human immunodeficiency virus-seropositive patients. Epilepsia. 1995;36(2):146-50.

55. Dore GJ, Law MG, Brew BJ. Prospective analysis of seizures occurring in human immunodeficiency virus type-1 infection. Journal of neuro-AIDS. 1996;1(4):59-69.

56. Miskin Dhanashri P, Herman Susan T, Ngo Long H, Koralnik IJ. Predictors and characteristics of seizures in survivors of progressive multifocal leukoencephalopathy. J Neuro-Oncol. 2016;22(4):464-71.

57. Tan K, Roda R, Ostrow L, McArthur J, Nath A. PML-IRIS in patients with HIV infection: clinical manifestations and treatment with steroids. Neurology. 2009;72(17):1458-64.

58. Khoury MN, Alsop DC, Agnihotri SP, Pfannl R, Wuthrich C, Ho ML, et al. Hyperintense cortical signal on magnetic resonance imaging reflects focal leukocortical encephalitis and seizure risk in progressive multifocal leukoencephalopathy. Ann Neurol. 2014;75(5):659-69.

59. Nurhak D, Ozlem C, Feray B, Veysi D, Zuhal Y, Cengiz Y, et al. A close look at EEG in subacute sclerosing panencephalitis. J Clin Neurophysiol. 2013;30(4): 348-56.

60. Olival KJ, Daszak P. The ecology of emerging neurotropic viruses. J NeuroOncol. 2005;11(5):441-6.

61. Chong HT. Seizures and epilepsies secondary to central nervous system infection. Neurol Asia. 2004;9(Suppl 1):20-3.

62. Salomão José Francisco M. The congenital Zika virus infection: still a puzzle. Childs Nerv Syst. 2017;34(1):61-2.

63. Sejvar JJ. Zika virus and other emerging Arboviral central nervous system infections. Continuum (Minneap Minn). 2018;24(5):1512-34.

64. Carvalho MXR, Montarroyos UR, da Silva P, Andrade-Valenca L, Eickmann SH. Early epilepsy in children with Zika-related microcephaly in a cohort in Recife, Brazil: characteristics, electroencephalographic findings, and treatment response. Epilepsia. 2020;61(3):509-18.
65. Moura da Silva AA, Ganz JS, Sousa PD, Doriqui MJ, Ribeiro MR, Branco MD, et al. Early growth and neurologic outcomes of infants with probable congenital Zika virus syndrome. Emerg Infect Dis. 2016;22(11):1953-6.

66. Schuler-Faccini L, Ribeiro EM, Feitosa IM, Horovitz DD, Cavalcanti DP, Pessoa A, et al. Possible association between Zika virus infection and microcephaly - Brazil, 2015. MMWR Morb Mortal Wkly Rep. 2016;65(3):59-62.

67. der Linden Vanessa V, André P, William D, James BA, Van der Linden JH, FEL R, et al. Description of 13 infants born during October 2015-January 2016 with congenital Zika virus infection without microcephaly at birth - Brazil. MMWR Morb Mortal Wkly Rep. 2016;65(47):1343-8.

68. Victor Alves L, Cavalcanti Sousa Cruz DD, van der Linden AMC, Rodrigues Falbo A, de Mello MJG, Esteves Paredes C, et al. Epileptic seizures in children with congenital Zika vírus syndrome. Revista Brasileira de Saúde Materno Infantil 2016;16(Suppl 1):S27-27S31.

69. Van der Linden H Jr, Carvalho MD, Van der Linden V, Lacerda KM, Pessoa A, Carneiro $\mathrm{ML}$, et al. Epilepsy profile in infants with congenital Zika virus infection. N Engl J Med. 2018;379(9):891-2.

70. Vezzani A, Fujinami RS, White HS, Preux PM, Blümcke I, Sander JW, et al. Infections, inflammation and epilepsy. Acta Neuropathol. 2016;131(2):211-34.

71. Bartolini L, Libbey JE, Ravizza T, Fujinami RS, Jacobson S, Gaillard WD. Viral triggers and inflammatory mechanisms in pediatric epilepsy. Mol Neurobiol. 2019;56(3):1897-907

72. Cusick MF, Libbey JE, Patel DC, Doty DJ, Fujinami RS. Infiltrating macrophages are key to the development of seizures following virus infection. J Virol. 2013;87(3):1849-60.

73. Kirkman NJ, Libbey JE, Wilcox KS, White HS, Fujinami RS. Innate but not adaptive immune responses contribute to behavioral seizures following viral infection. Epilepsia. 2010;51(3):454-64.

74. DePaula-Silva AB, Sonderegger FL, Libbey JE, Doty DJ, Fujinami RS. The immune response to picornavirus infection and the effect of immune manipulation on acute seizures. J Neuro-Oncol. 2018;24(4):464-77.

75. Libbey JE, Hanak TJ, Doty DJ, Wilcox KS, Fujinami RS. NBQX, a highly selective competitive antagonist of AMPA and KA ionotropic glutamate receptors, increases seizures and mortality following picornavirus infection. Exp Neurol. 2016;280:89-96.

76. Cusick MF, Libbey JE, Doty DJ, DePaula-Silva AB, Fujinami RS. The role of peripheral interleukin-6 in the development of acute seizures following virus encephalitis. J Neuro-Oncol. 2017;23(5):696-703.

77. Smeal RM, Stewart KA, lacob E, Fujinami RS, White HS, Wilcox KS. The activity within the CA3 excitatory network during Theiler's virus encephalitis is distinct from that observed during chronic epilepsy. J Neuro-Oncol. 2012; 18(1):30-44.

78. Smeal RM, Fujinami R, White HS, Wilcox KS. Decrease in CA3 inhibitory network activity during Theiler's virus encephalitis. Neurosci Lett. 2015;609:210-5.

79. Kim JV, Kang SS, Dustin ML, McGavern DB. Myelomonocytic cell recruitment causes fatal CNS vascular injury during acute viral meningitis. Nature. 2009; 457(7226):191-5.

80. Ransohoff RM. Immunology: barrier to electrical storms. Nature. 2009; 457(7226):155-6.

81. Loscher W, Gernert M, Heinemann U. Cell and gene therapies in epilepsy-promising avenues or blind alleys. Trends Neurosci. 2008;31(2):62-73.

82. Tunkel AR, Glaser CA, Bloch KC, Sejvar JJ, Marra CM, Roos KL, et al. The management of encephalitis: clinical practice guidelines by the Infectious Diseases Society of America. Clin Infect Dis. 2008;47(3):303-27.

83. Solomon T, Michael BD, Smith PE, Sanderson F, Davies NW, Hart IJ, et al. Management of suspected viral encephalitis in adults--Association of British Neurologists and British Infection Association National Guidelines. J Inf Secur. 2012;64(4):347-73.

84. Solomon T, Dung NM, Kneen R, Thao le TT, Gainsborough M, Nisalak A, et al. Seizures and raised intracranial pressure in Vietnamese patients with Japanese encephalitis. Brain. 2002;125(Pt 5):1084-1093.

85. Pandey S, Rathore C, Michael BD. Antiepileptic drugs for the primary and secondary prevention of seizures in viral encephalitis. Cochrane Database Syst Rev. 2016:5:CD010247.

86. Beleza P. Acute symptomatic seizures: a clinically oriented review. Neurologist. 2012;18(3):109-19.

87. Leung H, Man CB, Hui AC, Kwan P, Wong KS. Prognosticating acute symptomatic seizures using two different seizure outcomes. Epilepsia. 2010; 51(8):1570-9.

88. Gavvala JR, Schuele SU. New-onset seizure in adults and adolescents: A review. JAMA. 2016;316(24):2657-68. 
89. Kanner AM, Ashman E, Gloss D, Harden C, Bourgeois B, Bautista JF, et al. Practice guideline update summary: efficacy and tolerability of the new antiepileptic drugs I: treatment of new-onset epilepsy: report of the guideline development, dissemination, and implementation Subcommittee of the American Academy of neurology and the American Epilepsy Society. Neurology. 2018;91(2):74-81.

90. Schmidt D, Schachter SC. Drug treatment of epilepsy in adults. BMJ. 2014; 348:g254.

91. Chi X, Li R, Hao X, Chen J, Xiong W, Xu H, et al. Response to treatment schedules after the first antiepileptic drug failed. Epilepsia. 2018;59(11):2118-24.

92. Randomised study of antiepileptic drug withdrawal in patients in remission. Medical Research Council antiepileptic drug withdrawal study group. Lancet. 1991:337(8751):1175-80.

93. Practice parameter: a guideline for discontinuing antiepileptic drugs in seizure-free patients-summary statement. Report of the Quality Standards Subcommittee of the American Academy of Neurology. Neurology. 1996;47(2):600-2.

94. He RQ, Zeng QY, Zhu P, Bao YX, Zheng RY, Xu HQ. Risk of seizure relapse after antiepileptic drug withdrawal in adult patients with focal epilepsy. Epilepsy Behav. 2016;64(Pt A):233-8.

95. Brophy GM, Bell R, Claassen J, Alldredge B, Bleck TP, Glauser T, et al. Guidelines for the evaluation and management of status epilepticus. Neurocrit Care. 2012;17(1):3-23.

96. Riikonen R, Donner M. ACTH therapy in infantile spasms: side effects. Arch Dis Child. 1980;55(9):664-72.

97. D'Alonzo R, Rigante D, Mencaroni E, Esposito S. West syndrome: A review and guide for Paediatricians. Clin Drug Investig. 2018;38(2):113-24.

98. Riikonen R. Cytomegalovirus infection and infantile spasms. Dev Med Child Neurol. 1978;20(5):570-9.

99. Dunin-Wasowicz D, Kasprzyk-Obara J, Jurkiewicz E, Kapusta M, MilewskaBobula B. Infantile spasms and cytomegalovirus infection: antiviral and antiepileptic treatment. Dev Med Child Neurol. 2007;49(9):684-92.

100. Patsalos PN, Perucca E. Clinically important drug interactions in epilepsy: interactions between antiepileptic drugs and other drugs. Lancet Neurol. 2003;2(8):473-81.

101. Lertora JJ, Rege AB, Greenspan DL, Akula S, George WJ, Hyslop NE Jr, et al. Pharmacokinetic interaction between zidovudine and valproic acid in patients infected with human immunodeficiency virus. Clin Pharmacol Ther. 1994;56(3):272-8.

102. Hugen PW, Burger DM, Brinkman K, ter Hofstede HJ, Schuurman R, Koopmans PP, et al. Carbamazepine--indinavir interaction causes antiretroviral therapy failure. Ann Pharmacother. 2000;34(4):465-70.

103. Asconapé JJ. Pharmacokinetic considerations with the use of antiepileptic drugs in patients with HIV and organ transplants. Curr Neurol Neurosci Rep. 2018;18(12):89.

104. Trinka E, Dubeau F, Andermann F, Bastos A, Hui A, Li LM, et al. Clinical findings, imaging characteristics and outcome in catastrophic postencephalitic epilepsy. Epileptic Disord. 2000;2(3):153-62.

105. Cardarelli WJ, Smith BJ. The burden of epilepsy to patients and payers. Am J Manag Care. 2010;16(Suppl 12):S331-6.

106. Davies KG, Hermann BP, Wyler AR. Surgery for intractable epilepsy secondary to viral encephalitis. Br J Neurosurg. 1995;9(6):759-62.

107. Liu YO, Zhou WJ, Hong B, Zhao T, Wang YF. Surgical outcomes in patients with epilepsy after viral encephalitis: contribution of SEEG study. BMC Neurol. 2019;19(1):165.

108. Lancman ME, Morris HH. Epilepsy after central nervous system infection: clinical characteristics and outcome after epilepsy surgery. Epilepsy Res. 1996;25(3):285-90.

109. Lellouch-Tubiana A, Fohlen M, Robain O, Rozenberg F. Immunocytochemical characterization of long-term persistent immune activation in human brain after herpes simplex encephalitis. Neuropathol Appl Neurobiol. 2000;26(3):285-94.

110. Uda T, Koide R, Ito H, Hosono A, Sunaga S, Morino M. Relapse of herpes simplex virus encephalitis after surgical treatment for temporal lobe epilepsy: rare complication of epilepsy surgery. J Neurol. 2013;260(1):318-20.

111. Arnold A, Parkins MD, Hamilton LE, Hader W, Federico P. Recurrent herpes simplex virus encephalitis after epilepsy surgery. Can J Neurol Sci. 2019; 46(2):261-3

112. Barker-Haliski ML, Heck TD, Dahle EJ, Vanegas F, Pruess TH, Wilcox KS, et al. Acute treatment with minocycline, but not valproic acid, improves longterm behavioral outcomes in the Theiler's virus model of temporal lobe epilepsy. Epilepsia. 2016;57(12):1958-67.
113. Armangue T, Spatola M, Vlagea A, Mattozzi S, Carceles-Cordon M, MartinezHeras $E$, et al. Frequency, symptoms, risk factors, and outcomes of autoimmune encephalitis after herpes simplex encephalitis: a prospective observational study and retrospective analysis. Lancet Neurol. 2018;17(9): 760-72.

114. Pruss H, Finke C, Holtje M, Hofmann J, Klingbeil C, Probst C, et al. N-methylD-aspartate receptor antibodies in herpes simplex encephalitis. Ann Neurol. 2012;72(6):902-11.

115. Desena A, Graves D, Warnack W, Greenberg BM. Herpes simplex encephalitis as a potential cause of anti-N-methyl-D-aspartate receptor antibody encephalitis: report of 2 cases. JAMA Neurol. 2014;71(3):344-6.

116. Ellul MA, Griffiths MJ, lyer A, Avula S, Defres S, Baborie A, et al. Anti-Nmethyl-D-aspartate receptor encephalitis in A young child with histological evidence on brain biopsy of coexistent herpes simplex virus type 1 infection. Pediatr Infect Dis J. 2016:35(3):347-9.

117. Schein F, Gagneux-Brunon A, Antoine JC, Lavernhe S, Pillet S, Paul S, et al. Anti-N-methyl-D-aspartate receptor encephalitis after herpes simplex virusassociated encephalitis: an emerging disease with diagnosis and therapeutic challenges. Infection. 2017;45(4):545-9.

118. Wesselingh R, Butzkueven H, Buzzard K, Tarlinton D, O'Brien TJ, Monif M Seizures in autoimmune encephalitis: kindling the fire. Epilepsia. 2020. https://doi.org/10.1111/epi.16515.

119. Armangue T, Leypoldt F, Malaga I, Raspall-Chaure M, Marti I, Nichter C, et al. Herpes simplex virus encephalitis is a trigger of brain autoimmunity. Ann Neurol. 2014;75(2):317-23.

\section{Ready to submit your research? Choose BMC and benefit from:}

- fast, convenient online submission

- thorough peer review by experienced researchers in your field

- rapid publication on acceptance

- support for research data, including large and complex data types

- gold Open Access which fosters wider collaboration and increased citations

- maximum visibility for your research: over $100 \mathrm{M}$ website views per year

At $\mathrm{BMC}$, research is always in progress.

Learn more biomedcentral.com/submissions 